Сmaxiв O. O.,

stakhiv_o@gmail.com,

ORCIDID: 0000-0002-3774-8130,

аспірант кафедри адміністративного та кримінального права,

Дніпровський національний університет імені Олеся Гончара, м. Дніпро

\title{
СУЧАСНИЙ МЕТОД АДМІНІСТРАТИВНО-ПРАВОВОГО РЕГУЛЮВАННЯ СОЦІАЛЬНО-ТРУДОВИХ ВІДНОСИН В УКРАЇНІ В УМОВАХ ЄВРОІНТЕГРАЦІЇ
}

\begin{abstract}
Анотація. У статті розкривається зміст і специфіка сучасного методу адміністративно-правового регулювання соиіально-трудових відносин в Україні. Встановлено, щчо ознаками методу адміністративно-правового регулювання трудових відносин є ті його властивості, щцо закономірно і об'єктивно зумовлені предметом і власне методом адміністративно-правового регулювання. Доведено, що точність у визначенні способів адміністративно-правового регулювання, які впливають один на одного иляхом поєднання і співвідношення, дають змогу врахувати динамізм, трансформацію, диференціацію ознак соиіально-трудових відносин, формувати нові форми організаиії праиі, визначити подальше регулювання соиіально-трудових відносин на різних рівнях з метою оптимального поєднання $і$ врахування інтересів і на рівні підприємства, і на рівні галузі, і на рівні держави. Наголошується, що посилення договірних начал проявилось у відмові держави від регулювання деяких елементів соиіально-трудових відносин. Звернено увагу на певну зміну методу, який характеризується не лише поєднанням иентралізованого і локального, але й публічного і договірного регулювання сочіально-трудових відносин.

Наголомено, що в основу диференціачії адміністративно-правового регулювання соціально-трудових відносин, слід покласти спрямованість методу - способів адміністративно-правового регулювання: публічного (иентралізованого), колективно-договірного (локального) та індивідуальнодоговірного регулювання сочіально-трудових відносин, що будуть враховувати особливий підхід до регулювання спеціальних суб' 'ктів сочіально-трудових відносин, забезпечуючи таким чином рівність прав і можливостей у сфері праці всіх суб'єктів соиіально-трудових відносин. Встановлено, що одним з основних засобів забезпечення динамізму методу адміністративно-правового регулювання сочіальнотрудових відносин є запровадження багаторівневої системи адміністративно-правового регулювання, яка зумовлена насамперед дуалізмом самої сфери соиіально-трудових відносин, що поєднала в собі елементи публічного і приватного права. В якості напрямку розвитку вітчизняного законодавства вказано на посилення диференціації адміністративно-правового регулювання сочіально-трудових відносин, що свідчить про певну трансформацію методу, таку його рису, як єдність і диферениіація адміністративно-правового регулювання.
\end{abstract}

Ключові слова: адміністративно-правове регулювання, принципи адміністративно-правового регулювання, механізм адміністративно-правового регулювання, метод адміністративно-правового регулювання, соціальний діалог, соціально-трудові відносини, соціальне призначення.

Stakhiv O. O.,

stakhiv_o@gmail.com,

ORCID ID: 0000-0002-3774-8130,

Postgraduate Student at the Department of Administrative and Criminal Law,

Oles Honchar Dnipro National University, Dnipro

\section{MODERN METHOD OF ADMINISTRATIVE AND LEGAL REGULATION OF SOCIAL AND LABOR RELATIONS IN UKRAINE IN THE CONTEXT OF EUROPEAN INTEGRATION}

Abstract. The article reveals the specifics and content of the modern method of administrative and legal regulation of social and labour relations in Ukraine. It is argued that the signs of the method of administrativelegal regulation of labour relations are those properties that are objectively and naturally conditioned by the subject and actually by administrative-legal regulation. It is proved that accuracy in determining the methods 
of administrative-legal regulation, which affect each other by combination and ratio, allow you to take into account dynamism, transformation, differentiation of signs of social and labour relations, to form new forms of labour organization, to determine the further regulation of social and labour relations on the relevant Levels for optimal combination and taking into account various interests, both at the level of enterprise, industry and state. It is emphasized that the strengthening of the contractual principles manifested itself in the refusal of the state from the regulation of some elements of social and labour relations. This allows us to assert a certain change of the method that is characterized not only by a combination of centralized and local, but also state and contractual regulation of labour and other directly related relationships.

It is emphasized that the differentiation of administrative-legal regulation of social and labour relations should be put forward the direction of the method - methods of administrative and legal regulation: state (centralized), collective-contractual (local) and individual contractual regulation of social and labour relations, which will take into account A special approach to the regulation of special subjects of social and labour relations, thus ensuring the equality of rights and opportunities in the work of all subjects of social and labour relations. It has been established that one of the main means of ensuring the dynamism of the method of administrative-legal regulation of social and labour relations is the introduction of a multi-level administrative-legal regulation system, which is predetermined, first of all, by dualism of the sphere of social and labour relations, which combines elements of public and private law. As a direction in the development of domestic legislation, it is indicated on the strengthening of the differentiation of administrative and legal regulation of social and labour relations, indicating a certain transformation of the method, such its rice as unity and differentiation of administrative and legal regulation.

Key words: administrative-legal regulation, principles of administrative-legal regulation, mechanism of administrative-legal regulation, method of administrative-legal regulation, social dialogue, social and labour relations, social purpose.

\section{JEL Classification: K 31, K 23 \\ DOI: 10.36477/2616-7611-2021-10-08}

Постановка проблеми. Сьогодні відбувається становлення і подальший розвиток нової епохи, що відкриває принципово нові інтелектуальні технології, нову мотивацію праці, нові форми і методи іiі організації та нові потреби і цінності, що зумовлює, своєю чергою, відповідні зміни у видах і формах існування соціально-трудових відносин. Отже, формується важливе завдання: запровадження певних методів ставлення до працівника. Крім того, умови євроінтеграції потребують уточнення i корегування теоретичних підходів до проблем адміністративно-правового регулювання суспільних відносин практично у всіх сферах, у тому числі й у сфері соціальнотрудових відносин. Очевидним виглядає факт необхідності вдосконалення самого механізму адміністративно-правового регулювання сфери соціально-трудових відносин. Це, своєю чергою, передбачає необхідність розробки тих теоретичних конструкцій, які враховують сучасні реалії, особливо в процесі так званої глобалізації, де провідне місце належить економіці, а економічною основою будь-якого суспільства є виробництво і передача інформації. Зміни економічної основи суспільства обов'язково спричинюють значні реформи в інших сферах життя суспільства. Зміни ж соціальних умов невідворотно вплинули на сферу законодавства. А тому адмі- ністративне право зазнає певних змін, відповідно до сучасних сформованих або таких, що починають формуватися, соціально-трудових відносин. Прагнення вийти на міжнародний рівень стандартів, необхідність обгрунтування сучасної доктрини адміністративного права стали своєрідним поштовхом і здійснили суттєвий вплив як на суспільні відносини, так і на адміністративно-правове регулювання соціально-трудових відносин.

Аналіз останніх досліджень і публікацій. Окремі аспекти методу адміністративно-правового регулювання сфери соціально-трудових відносин та визначення ролі органів публічної адміністрації в цьому процесі висвітлюють у своїх працях відомі вітчизняні вчені: В. Авер'янов, I. Арістова, Г. Атаманчук, О. Баїк, О. Бандурка, Ю. Битяк, М. Бліхар, В. Богуцький, Н. Бортник, Т. Василевська, М. Гаращук, Д. Голосніченко, І. Голосніченко, В. Гриньова, С. Гусаров, О. Дніпров, В. Зуй, Є. Додін, С. Ківалов, С. Ковалевська, М. Ковалів, Т. Коломоєць, В. Колпаков, Н. Лесько, І. Личенко, А. Мельник, М. Мельник, В. Ортинський, Н. Ортинська, У. Парпан, І. Пахомов, Л. Попова, І. Самсін, О. Сушинський, О. Хитра, Л. Чистоклетов, А. Школик та інші науковці. Проте дослідники в основному концентрують свою увагу на характерних рисах самого змісту соціально-трудових відносин, правовій характе- 
ристиці суб'єктів соціально-трудових відносин. Звісно, це також заслуговує на увагу, але саме метод адміністративно-правового регулювання сфери соціально-трудових відносин передбачає відповідний процес, який повинен включати відповідну стадійність у його регулюванні, характеристику всіх засобів впливу на свідомість і поведінку суб'єктів. У зв' язку із цим існує необхідність здійснення окремого наукового дослідження адміністративно-правового регулювання сфери соціально-трудових відносин в умовах євроінтеграції.

Постановка завдання. Метою статті $\epsilon$ узагальнення науково-теоретичних підходів до визначення сутності та змісту сучасного методу адміністративно-правового регулювання сфери соціально-трудових відносин.

Виклад основного матеріалу дослідження. Сучасному методу адміністративно-правового регулювання сфери соціально-трудових відносин властивий комплексний характер. У сучасній науці адміністративного права при визначенні методу, як правило, виділяють такі специфічні його особливості: особливості правового становища суб' єктів; поєднання централізованого, локального та індивідуального правового регулювання соціально-трудових відносин; єдність і диференціація адміністративно-правового регулювання соціально-трудових відносин; участь працівників та їх об'єднань у формуванні змісту соціально-трудових відносин; локальне адміністративно-правове регулювання соціально-трудових відносин; наявність специфічних способів захисту порушених прав учасників правовідносин; співвідношення (поєднання) договірного, рекомендаційного та імперативного способів адміністративно-правового регулювання; специфічність способів захисту і самозахисту трудових прав і забезпечення обов'язків; рівність сторін трудового договору з підпорядкуванням їх в процесі роботи внутрішньому трудовому розпорядку організації; диференціація адміністративно-правового регулювання; залежність винагороди від колективних та індивідуальних результатів діяльності [1, с. 89].

Кожен компонент зумовлений специфікою і динамізмом суспільних відносин. Системнокомпонентний підхід під час аналізу методу адміністративно-правового регулювання соціально-трудових відносин дає змогу синтезувати особливості i фрагментарні характеристики компонентів, що $\epsilon$ його складовою як єдиного об'єкта вивчення. Водночас слід зупинитися на окремих моментах. Безсумнівно, що всі пере- раховані ознаки, так або інакше характеризують особливості не методу адміністративно-правового регулювання, а здебільш особливості соціально-трудових відносин (зокрема, рівність сторін трудового договору 3 підпорядкуванням їх в процесі роботи внутрішньому трудовому розпорядку організації, договірний порядок праці та визначення іiі умов тощо) [2, с. 23]. Мабуть, так і повинно бути, оскільки метод адміністративноправового регулювання соціально-трудових відносин взаємозумовлений предметом і піддавався вивченню саме через його призму. У цьому також $\epsilon$ сенс, оскільки саме завдяки соціально-трудовим відносинам метод, як та «губка», неначе всмоктує в себе специфічні їх властивості, що дають змогу глибше з'ясувати саму сутність права та його окремі елементи, набуваючи водночас конкретної спрямованості, мети, що виявляється в завданнях самої галузі. Тому це $\epsilon$ основною специфічною рисою методу адміністративно-правового регулювання соціально-трудових відносин.

Адміністративно-правове регулювання, крім встановлення правових меж для договірних відносин вказаних вище суб'єктів, виявляється в функціонуванні у сфері соціально-трудових відносин різних публічних органів, відносини яких 3 роботодавцями та громадянами містять вкрай мало договірних елементів і спрямовані на забезпечення нормального функціонування соціально-трудових відносин [3, с. 76-77]. Водночас, така подвійна природа відносин, що поєднує в собі приватноправові і публічно-правові елементи, дала підстави окремим ученим зробити висновки про те, що окремі інститути соціальнотрудових відносин можуть регулюватися різними галузями права, зокрема адміністративного, а звідси - застосовуватися різні методи адміністративно-правового регулювання, використовуватися адміністративно-правові засоби, що першочергово склалися в інших галузях. Звідси набула поширення точка зору окремих авторів про розчинення галузі трудового права в адміністративному, проголошувалася криза галузі трудового права як такої [4, с. 211].

Співвідношення диспозитивних та імперативних норм $є$ неоднаковим у різних галузях права, і залежить, передусім, від співвідношення в них приватних і публічних начал. Диспозитивність адміністративно-правового регулювання може виявлятися не лише в змісті норм права, але й у можливості вибору сторонами однієї з передбачених законом альтернатив, одного із варіантів поведінки [5, с. 77-78]. Сторони соціально-трудо- 
вих відносин за своєю ініціативою можуть самостійно врегулювати свої відносини з тими лише обмеженнями, що нові умови не можуть погіршувати становище працівників. Саме тут поєднується можливість встановлювати нові правила поведінки в договірному порядку з пріоритетним захистом більш слабкої сторони соціально-трудових відносин - працівників.

Таким чином, в адміністративному праві яскраво проявляється така ознака методу, як поєднання (співвідношення) державного (централізованого), колективно-договірного та індивідуально-договірного регулювання відносин у сфері соціально-трудових відносин.

Співвідношення рівнів адміністративно-правового регулювання постійно змінюється, формуються нові моделі поєднання рівнів, що своєю чергою свідчить про те, що відбувається зміна та вдосконалення адміністративно-правового регулювання соціально-трудових відносин, внаслідок якого відбувається трансформація, диференціація ознак соціально-трудових правовідносин, що традиційно виділялися в науковій літературі, що $\epsilon$ неминучою відповіддю на вимоги нового часу, внаслідок якого розвиваються та з'являються нові форми організації праці, такі як «нетипова» трудова зайнятість тощо. Слід погодитися, що відбувається динамізм адміністративного права в цілому та динамізм соціально-трудових відносин зокрема [6, с. 99]. Цьому сприяє деякою мірою децентралізація i багаторівневість адміністративно-правового регулювання соціальнотрудових відносин. Використання декількох рівнів адміністративно-правового регулювання дозволяє створити таке поєднання загального та особливого в соціально-трудових відносинах, за якого можливе врахування інтересів усіх суб'єктів адміністративного права [7, с. 178].

В умовах євроінтеграції адміністративно-правове регулювання соціально-трудових відносин має оперативно реагувати на зміни, що відбуваються в суспільстві, тобто воно повинно бути гнучким, а це означає, що саме динамізм адміністративно-правового регулювання повинен стати головною рушійною силою, певним орієнтиром розвитку адміністративного права. Саме ця обставина завжди, на всіх етапах історичного розвитку адміністративного права визначала принципові особливості методу адміністративно-правового регулювання соціально-трудових відносин: статика і динаміка, як правило, зумовлювали централізацію і децентралізацію [8, с. 245]. Так публічне регулювання втрачає колишню жорстку імпе- ративність, на фоні розвитку соціального партнерства, але набуває нового характеру - загальні вихідні начала регулювання, мінімальні гарантії встановлюються саме на централізованому рівні.

Особливий правовий статус суб'єктів соціально-трудових відносин, і в першу чергу працівника як найбільш слабкої сторони, породжує наступну важливу ознаку методу адміністративного права - особливий характер захисту прав та інтересів суб'єктів соціально-трудових відносин. Водночас, дефініція «захист трудових прав» застосовується в різних значеннях як у законодавстві, так і в науковій літературі. А отже, внести більшу точність можливо, якщо розділити поняття охорони і захисту прав, що вже неодноразово підкреслювалося в юридичній літературі.

Отже, в методі адміністративного права яскраво проявляється соціальне призначення адміністративного права, яке виражається в напрямках його впливу на соціально-трудові відносини, пронизується в принципах, реалізується насамперед через норми, нормативно-правові акти, що закріплюють здебільшого певні гарантії здійснення прав і законних інтересів працівників та «супроводжують» їх у процесі всієї трудової діяльності - від працевлаштування аж до звільнення (виходу на пенсію) [9, с. 36]. Спираючись на наукові дослідження сучасних учених у галузі права соціального забезпечення, можна зробити висновок про те, що інститут обов'язкового соціального страхування «став повноцінною частиною права соціального забезпечення, оскільки ні цивільно-правовий спосіб, ні адміністративно-правовий спосіб регулювання в чистому вигляді не могли забезпечити реальний захист прав та інтересів потерпілих від нещасних випадків на виробництві та членів їх сімей: перший - через неможливість регулювання економічних відносин виключно методами влади і підпорядкування, а другий - унаслідок закріплення формальної юридичної, а не фактичної рівності учасників [10, с. 97].

Єдність i диференціація адміністративноправового регулювання мають власні зовнішні та внутрішні передумови. Зовнішньою передумовою єдності і диференціації адміністративного права як галузі права $\epsilon$ взаємообумовленість публічного і приватного права (його елементів), завдяки чому адміністративне право призначене обслуговувати само себе, відповідно до мети, завдань і функцій. Тому утворення адміністративного права як самостійної галузі права з іiї предметом, методом та принципами регулювання, які 
$€$ відмінними за своєю суттю і змістовним наповненням від інших галузей права - не данина історичній традиції, а об'єктивні закономірності, в основі яких лежить межа співвідношення приватних і публічних інтересів [11, с. 108-109]. Це своєю чергою зумовлює зовнішню як єдність, так і диференціацію адміністративно-правового регулювання соціально-трудових відносин.

Диференціація адміністративно-правового регулювання соціально-трудових відносин необхідна, однак визначальним началом (основою) правового регулювання є те, що об'єднує його в єдине ціле - праця людини як діяльність, що складає серцевину змісту соціально-трудових відносин. Тому внутрішня єдність і диференціація адміністративно-правового регулювання соціально-трудових відносин визначаються предметом, методом і принципами адміністративного права як системи норм права (норм-принципів), що регламентують відносини, які виникають i розвиваються в процесі використання найманої праці. Необхідність диференціації в адміністративно-правовому регулюванні соціальнотрудових відносин, не означає обов'язкового виникнення нових критеріїв, способів адміністративно-правового регулювання праці, приєднання до неї нових правових явищ [12, с. 306]. Метод адміністративно-правового регулювання трудових відносин за своїм змістовним наповненням уже поєднує в собі, відповідно до специфіки предмету, публічне (централізоване), колективнодоговірне (локальне) та індивідуально-договірне регулювання, де проявляється єдність і диференціація, а тому й дає змогу максимально врахувати особливості цього адміністративно-правового регулювання при дотриманні знову ж таки принципу «непогіршення умов праці».

Наступною специфічною ознакою методу адміністративного права $\epsilon$ рівність (рівноправність) прав і можливостей його суб'єктів взагалі і суб'єктів соціально-трудових відносин зокрема у рамках певних груп працівників, роботодавців. Але специфіка цієї ознаки полягає не в назві, а в тому, що наповнює змістовно названий принцип. Звісно, працівник і роботодавець не можуть бути рівноправними партнерами у буквальному розумінні цього слова. Не можуть 3 тієї простої причини, що роботодавець, як правило, виступає власником засобів виробництва, а працівник надає свою робочу силу відповідно до своїх здібностей, інтелекту, іншими словами, відповідно до своїх розумових і фізичних можливостей $[13$, с. 114]. 3 іншого боку, в інтересах розвитку виробництва, покращення матеріального достатку, що необхідно і для суспільства, і для держави, трудове право, шляхом поєднання (співвідношення) способів адміністративно-правового регулювання повинно визначити правове становище працівника i роботодавця шляхом встановлення прав, обов'язків, гарантій і заходів відповідальності. У цьому випадку йдеться не про рівність у обсязі прав і обов'язків як працівника, так і роботодавця (на відміну між окремими групами працівників і роботодавців), а про встановлення для сторін однакових можливостей впливати на долю трудового правовідношення 3 точки зору його виникнення, зміни та припинення. Про це також свого часу зауважувалося в юридичній літературі [14, с. 74]. Зважаючи на принцип свободи праці, рівність сторін полягає передусім у тому, що норми трудового законодавства є обов' язковими для виконання як працівниками, так і роботодавцями. У юридичній літературі побутує думка про те, що становище сторін характеризується поєднанням рівності суб'єктів сторін трудового договору в момент укладення трудового договору і взяття на себе працівником обов'язку підкорення владі роботодавця у процесі здійснення трудової функції.

Оскільки соціально-трудові відносини виникають та існують у часі виключно на підставі трудового договору, то й, як правило, вчені виділяють у якості самостійної риси методу трудового права «договірний характер праці».

Договірний характер властивий укладенню будь-якої угоди. В умовах євроінтеграції саме угода лежить в основі виникнення та зміни соціально-трудових відносин. Це твердження не викликає сумнівів. В основі виникнення і динаміки трудових правовідносин лежать дії його суб'єктів. Договірний характер виявляється в індивідуально-договірному (трудовий договір) і в колективно-договірному (колективні договори i угоди) правовому регулюванні. Розширення договірного регулювання трудових відносин $\epsilon$ сьогодні однією з основних тенденцій розвитку трудового права. Посилення договірних начал виражається перш за все в тому, що на законодавчому рівні закріплено можливість регулювання трудових і безпосередньо пов'язаних з ними відносин шляхом укладення колективних договорів, угод, трудових договорів. Водночас, договірний характер методу адміністративного права проявляється, як правило, не стільки при укладенні трудового договору, скільки у відносинах соціального партнерства. 
В умовах євроінтеграції договірне регулювання займає значне місце в регулюванні відносин у сфері соціально-трудових відносин. Держава сьогодні не регулює всі нюанси соціально-трудових відносин, а встановлює лише мінімальні гарантії у сфері праці. Всі інші компоненти існування соціально-трудових відносин визначаються на рівні конкретної організації (роботодавця) [15, с. 47]. В умовах ринкової економіки відносини між працівниками та роботодавцями засновані на свободі, самостійності та саморегулюванні. Це проявляється у розширенні сфери індивідуально-договірного та локального регулювання, розвитку інституту соціального партнерства, усуненні держави від прямого адміністративно-правового регулювання у сфері соціально-трудових відносин.

Висновки. Таким чином, сучасним методом адміністративно-правового регулювання сфери соціально-трудових відносин є система взаємопов'язаних і взаємообумовлених адміністративно-правових засобів, які виражають основні особливості соціально-трудових відносин та за допомогою яких здійснюється вплив на свідомість і поведінку суб'єктів соціально-трудових відносин. У методі адміністративно-правового регулювання сфери соціально-трудових відносин відображається та характеристика правового адміністративно-впливу, яка склалася завдяки об'єктивним чинникам і відображає специфіку соціально-трудових відносин, що підлягає адміністративно-правовому регулюванню. Складна і водночас тісна компонентна складова елементів методу адміністративно-правового регулювання сфери соціально-трудових відносин дає змогу розглядати його як системне утворення, оскільки адміністративно-правове регулювання соціально-трудових відносин не може забезпечити жоден із елементів методу самостійно, воно здійснюється одночасно всіма його компонентами в їх органічному взаємозв'язку і завдяки наявності цих зв'язків. 3 цих позицій визначати метод адміністративно-правового регулювання необхідно не як сукупність, а як систему саме у змістовному його значенні. Елементами методу як системи виступають специфічні прийоми, способи, засоби, властивості та юридичні особливості впливу адміністративно-правових норм на соціально-трудові відносини. Своєрідність методу розкривається не через якусь окрему ознаку, а через всі ознаки в сукупності, що проявляють свою взаємодію в системі. Ознаками методу адміністративно-правового регулювання сфери соціально-трудових відносин є такі його властивості, що об'єктивно і закономірно зумовлені предметом і власне методом адміністративно-правового регулювання.

\section{ЛІТЕРАТУРА:}

1. Процевський В.О. Приватно-правове та публічно-правове регулювання соціально-трудових відносин : монографія. Харків : ХНАДУ, 2012. $332 \mathrm{c}$.

2. Алексейчук В.В. Теоретичні підходи до обгрунтування сутності поняття соціального партнерства. Держава та регіони. 2009. № 1. С. 22-25.

3. Міщук М.А. Способи вирішення проблем соціального партнерства у трудовому праві. Visegrad journal on human rights. 2015. № 3/1. C. 75-79.

4. Діденко Н. Державне управління і соціальне партнерство: актуальні проблеми теорії і практики : монографія. Донецьк : Східний видавничий дім, 2007. 404 c.

5. Трунова Г.А. Правове регулювання соціального партнерства в Україні : дис. ... канд. юрид. наук : спец. 12.00.05. Харків, 2008. 213 с.

6. Мірошниченко О.В. Розвиток соціально-трудового партнерства в Україні: методологія, методика аналізу, напрямки вдосконалення : монографія. Київ : РВПСУ, 2003. 187 с

7. Соціально-трудові відносини: проблеми гармонізації : колективна монографія / М.В. Семикіна, 3.В. Смутчак, С.Р. Пасєка, Ю.Д. Петров. Кіровоград : КНТУ, КОД, 2012. 300 с.

8. Соціалізація відносин у сфері праці в контексті стійкого розвитку / А.М. Колот, О.А. Грішнова, О.О. Герасименко та ін. ; за наук. ред. д-ра екон. наук, проф. А.М. Колота. Київ : КНЕУ, 2010. 348 с.

9. Колот А.М. Соціально-трудова сфера : стан відносин, нові виклики, тенденції розвитку. Київ : KHEУ, 2010. $251 \mathrm{c}$.

10. Терон І.В. Модернізація соціально-трудових відносин: сценарії, пріоритети, ефекти. Економічний часопис-XXI. 2013. № 7-8 (1). С. 97-100.

11. Семикіна М.В., Бевз 3.В. Гармонізація соціально-трудових відносин: методологія оцінки впливових чинників. Зб. наук. пр. Кіровоград. нац. техн. ун-ту: економічні науки. Вип. 18 (Ч. 1). Кіровоград : КНТУ, 2010. С. 106-114.

12. Мельник С.В. Механізм регулювання соціально-трудової сфери України. Київ : Соцінформ, 2009. $478 \mathrm{c}$.

13. Жадан О.В. Соціально-трудові відносини як об'єкт державного регулювання. Економіка та держава. 2014. № 5. С. 112-115.

14. Лавріненко О.В. Механізм правового регулювання соціально-трудових відносин : сучасний стан та перспективи розвитку : монографія. Донецьк : Норд-Прес - ДЮІ ЛДУВС, 2007. 182 с. 
15. Біляцький С., Хахлюк А., Мірошніченко Т. Соціальне партнерство у розв'язанні проблем зайнятості (приклад ЄС для України). Україна: аспекти пращі. 2003. № 3. С. 44-49.

\section{REFERENCES:}

1. Protsevskyi, V.O. Pryvatno-pravove ta publichno-pravove rehuliuvannia sotsialno-trudovykh vidnosyn : monohrafiia. Kharkiv : KhNADU, 2012.332 s.

2. Alekseichuk, V.V. Teoretychni pidkhody do obgruntuvannia sutnosti poniattia sotsialnoho partnerstva. Derzhava ta rehiony. 2009. № 1. S. 22-25.

3. Mishchuk, M.A. Sposoby vyrishennia problem sotsialnoho partnerstva u trudovomu pravi. Visegrad journal on human rights. 2015. № 3/1. S. 75-79.

4. Didenko, N. Derzhavne upravlinnia i sotsialne partnerstvo: aktualni problemy teorii i praktyky : monohrafiia. Donetsk : Skhidnyi vydavnychyi dim, 2007. $404 \mathrm{~s}$.

5. Trunova, H.A. Pravove rehuliuvannia sotsialnoho partnerstva v Ukraini : dys. ... kand. yuryd. nauk : spets. 12.00.05. Kharkiv, 2008. $213 \mathrm{~s}$.

6. Miroshnychenko, O.V. Rozvytok sotsialno-trudovoho partnerstva v Ukraini : metodolohiia, metodyka analizu, napriamky vdoskonalennia : monohrafiia. Kyiv : RVPSU, 2003. 187 c

7. Sotsialno-trudovi vidnosyny: problemy harmonizatsii : kolektyvna monohrafiia / M.V. Semykina, Z.V. Smutchak, S.R. Pasieka, Yu.D. Petrov. Kirovohrad : KNTU, KOD, 2012. 300 s.
8. Sotsializatsiia vidnosyn u sferi pratsi v konteksti stiikoho rozvytku / A. M. Kolot, O.A. Hrishnova, O.O. Herasymenko ta in. ; za nauk. red. d-ra ekon. nauk, prof. A. M. Kolota. Kyiv : KNEU, 2010. 348 s.

9. Kolot, A.M. Sotsialno-trudova sfera : stan vidnosyn, novi vyklyky, tendentsii rozvytku. Kyiv : KNEU, 2010. $251 \mathrm{~s}$.

10. Teron, I.V. Modernizatsiia sotsialno-trudovykh vidnosyn: stsenarii, priorytety, efekty. Ekonomichnyi chasopys-KhKhI. 2013. № 7-8 (1). S. 97-100.

11. Semykina, M.V., Bevz, Z.V. Harmonizatsiia sotsialno-trudovykh vidnosyn: metodolohiia otsinky vplyvovykh chynnykiv. Zb. nauk. pr. Kirovohrad. nats. tekhn. un-tu: ekonomichni nauky. Vyp. 18 (Ch. 1). Kirovohrad : KNTU, 2010. S. 106-114.

12. Melnyk, S.V. Mekhanizm rehuliuvannia sotsialno-trudovoi sfery Ukrainy. Kyiv : Sotsinform, 2009. $478 \mathrm{~s}$.

13. Zhadan, O.V. Sotsialno-trudovi vidnosyny yak ob'iekt derzhavnoho rehuliuvannia. Ekonomika ta derzhava. 2014. № 5. S. 112-115.

14. Lavrinenko, O.V. Mekhanizm pravovoho rehuliuvannia sotsialno-trudovykh vidnosyn : suchasnyi stan ta perspektyvy rozvytku : monohrafiia. Donetsk : Nord-Pres - DIuI LDUVS, 2007. $182 \mathrm{~s}$.

15. Biliatskyi S., Khakhliuk A., Miroshnichenko T. Sotsialne partnerstvo u rozv'iazanni problem zainiatosti (pryklad YeS dlia Ukrainy). Ukraina: aspekty pratsi. 2003. № 3. S. 44-49.

Стаття надійшла до редакиії 31.08.2021 